\title{
Work Life Balance (WLB) and Flexibility in Paid Work (FPW) for "Generation Y": A Discussion
}

\author{
Fotios V. Mitsakis (Corresponding author) \\ Dept. of Human Resource Management, University of Strathclyde \\ Glasgow G1 1XU, Scotland \\ E-mails: fotis.mitsakis@strath.ac.uk or fotisathens@hotmail.com
}

Georgios Talampekos

E-Commerce Professional, Athens, Greece

E-mail: gtalampekos@yahoo.gr

Received: April 12, 2014 Accepted: May 2, $2014 \quad$ Published: May 18, 2014

doi:10.5296/bmh.v2i1.5466 URL: http://dx.doi.org/10.5296/bmh.v2i1.5466

\begin{abstract}
For many years, the provision of WLB/FPW was offered as an incentive from HR departments to their workforce. However, in the last decade, certain demographic trends and changes in the needs and the nature of the workforce upgraded the WLB/FPW concept to a more significant factor of business growth and competitiveness. The aim of this paper is to demonstrate the need for WLB/FPW in the equation of recruitment and retention of "generation $\mathrm{Y}$ " employees as a vital factor of the staffing policies and strategies in the forthcoming years.
\end{abstract}

Keywords: Work-life balance (WLB), Flexibility in paid work (FPW), Generation Y, Talent shortage in the developed economies 


\section{Introduction}

For many years since the introduction of the WLB concept within the corporate activities, during the late 1970s, along with FPW, both concepts were considered as supportive elements of the organizational operations. Additionally, the provision of WLB/FPW was offered as an incentive from HR departments, usually targeting working mothers, by providing them with the form of part-time work or work-family benefits (Kimmel, 1993, 2000), since women represent a large percentage of undergraduates worldwide, while, nowadays, men play a more active role in home and family responsibility and caring (Gambles et al., 2006). However, in the last decade, certain demographic trends and changes in the needs and the nature of the workforce upgraded the WLB/FPW concept to a more significant factor of business growth and competitiveness within the recruitment field. Moreover, two fundamental factors, namely the constant increase of the work hours within the cost-cutting oriented work environment and the on-going economic downturn which reduced the payroll budgets, both will render the alternative sources of compensation critical to organizations' recruitment policies.

The main idea of this article lies in evidence that will render WLB/FPW a valuable source of employees' recruitment and retention in organizations of developed countries, where the war of talent will become fierce in near future. Especially for certain workforce pools/generations, the talent drain, in developed countries, becomes more obvious, while developing countries struggle to increase their career-offered attractiveness and to enhance their employer status in terms of opportunities for personal development and rewarding. Baby boomers, as founders and insiders of the traditional work ethic and work settings, shaped the pattern of the authoritarian/hierarchical work structure and concurrently they preserved many features of the "Weberian" puritan work ethic. The inflexible work systems derived from this generation still can be evidenced within many management and work practices, although, most of the time are incompatible with the function and the demands of today's WLB/FPW concept. On the other hand, generation X (born in 1965-1979) concentrates at various elements that constitute them as more of a transitional generation relative to the one that is the focus of this article (generation Y). Finally, the employable population of "generation Y" display intrinsic characteristics and work attitudes that nicely fit the concept of WLB/FPW. It is the most diverse work population, in terms of personal needs and preferences in career progression, which an "agile workplace” looks for (Belkin, 2006). Additionally, "generation Y" employees appear to be more familiar and receptive to technology and alternative work styles, both representing useful elements over certain flexible work practices like telecommuting, job sharing etc. Economist's (2006) special report highlighted that people of this generation are young talented employees who look skeptically at the idea of a life-time employment within a single organization, while being wary of any kind of commitment including the job; hence, they are looking for a work style that suits their lifestyle. Additional demographic trends, such as the declining birth rates, baby boomers' retirement, and changes in the nature of the workforce render "generation Y" as a crucial employment pool. 


\section{Generation $\mathbf{Y}$}

Generation Y (people in ages 15-30) is expected to represent the key labor market pool of the future. A number of factors lay this generation as being a vital part of the social and business context the following years. In that event, the way in which this generation of employees will be treated and settled within the work place (physical or not) will dictate the way of doing business, individuals' quality of life, and the resources, both in human and natural terms, that are required for any future business developments. Several authors among the literature identified the distinctive features along with the motivational drivers of this generation. For example, Levinson (1996) argued that new generation employees do not expect long term relationships from their employers, and eventually are not so dependent on any job or organization. The author further noted that they no longer seek for their employer's support, since they are responsible for their personal and career development. In this respect, employees are now interested in strengthening and enhancing their employability and personal development through constant training, gained experiences from various tasks and jobs throughout a non-linear career. Employees of "generation Y" also seem to demonstrate more individualistic behaviors and self-reliance within the working context (Jones et al., 2006), while concurrently, they seem to have a preference to those companies demonstrating corporate social responsibility (Aguirre et al. 2009). That can also be demonstrated through the findings of Smith's (2010) study which highlighted that employees of this generation are considerably regard WLB options as an important indicator of a person's job quality, job performance, job satisfaction and commitment, and a precursor of ethical decision-making individuals.

Further down, there are several exogenous factors demonstrating this generation's distinctive characteristics. For example, Morton (2002) highlighted generation's Y increased diversity, equality and tolerance regarding their working and personal lives. The author further asserted that "generation $\mathrm{Y}$ " employees value those jobs providing continuous training and development initiatives, along with equal employment opportunities for their workforce. If these conditions do not be present, then Generation Y employees will look for new challenges in their working lives by moving to a new work (Kerslake, 2005). To that end, Martin (2005) argued that organizations need to adjust their training and development policies to the needs of this generation workers which will constitute their future manpower. Economist Intelligence Unit's (EIU) (2008) report noted that the talent pool, within the developed world, is evaporating at an alarming rate, by stating that: "Baby boomers are beginning to retire, and birth rates across most developed countries are slowing dramatically. Retirees, meanwhile, are taking with them valuable experience and knowledge and leaving big gaps in the workforce. For example, the US will face a labor shortfall of 5.6m people by 2010 due to an ageing population, and Germany is increasingly recruiting "silver workers" (previously retired employees) to fill gaps in their workforce. - over the next two decades, the baby boomers will retire, taking with them a wealth of hard-to-replace experience, industry-specific knowledge, and long-term customer relationships". This assertion can also be supported through the following graph illustrating the "ratio of working age to dependent population”, as reported by Bloom and Canning (2005). 


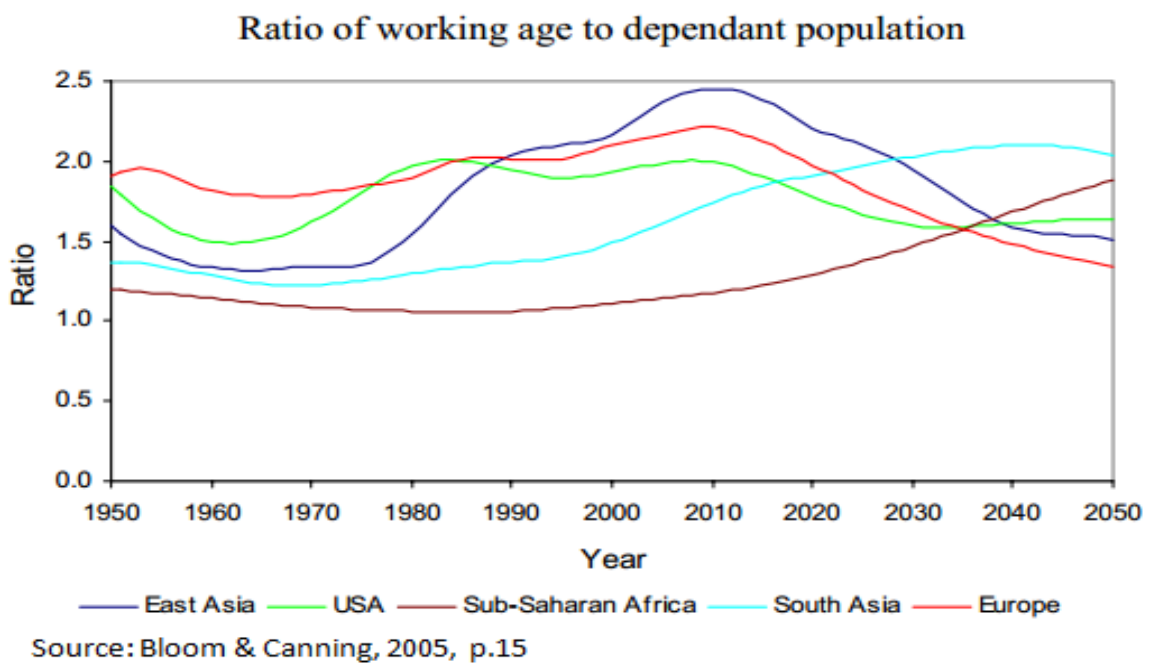

Accordingly, Aguirre et al. (2009) outlined a forthcoming reality for mature economies and their population that is no longer employable. In fact, they identified certain key economies (e.g. Germany, Japan, US etc.) in which the swelling rank of retirees is combined with low birth rates_-particularly among the college educated-and immigration policies in order to fuel a reduction in the working-age population (20-40\%) within the next decades. Additionally, in accordance to age-related challenges, the authors highlighted to business leaders the increasing demand of considering the generational composition of their manpower, by outlining that: "They are managing a workforce that includes three distinct generations; the traditional one-size-fits-all approach to talent management is no longer effective. The millennial generation, also known as generation $Y$, is the next huge population swells entering the system. Generation Y, ages 15 through 30, is even bigger than the baby-boom generation; in fact, by 2025 this generation will make up 60 to 75 percent of the global workforce" (ibid.). Appropriately, they illustrated their model of workforce's transition, which presents the shift to talent management for the $21^{\text {st }}$ century along with its characteristics within the work structure and environment.
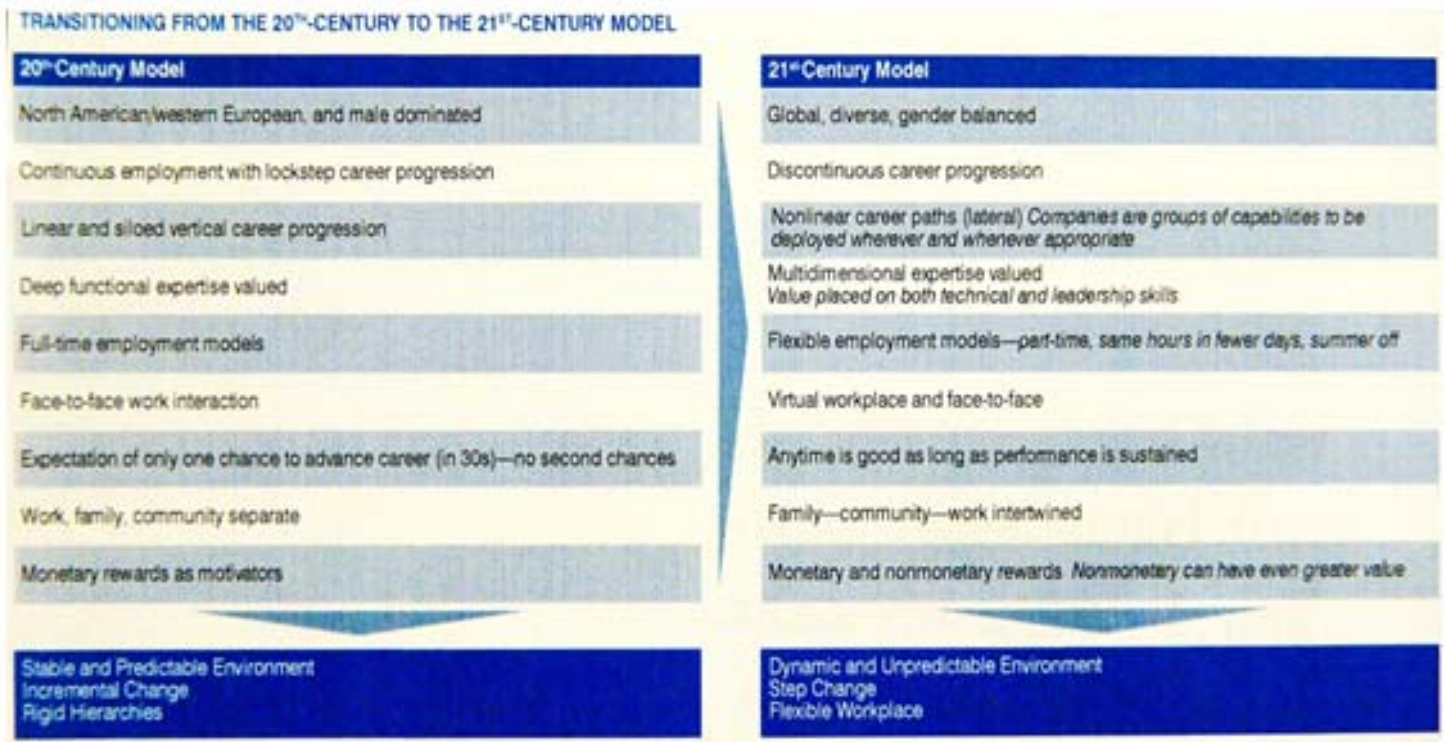

Source: Aguirre et al., 2009 


\section{Macrothink

Apparently, it is crucial for organizations and societies to be fully aware of people's changing and evolving needs and interests in order to effectively match them with their internal functions and structures, and accordingly to avoid assuming that frameworks shaped back in the 1950s and 1960s can work forever. In that way, both organizations and societies can gain a significant advantage to the only factor which cannot be replicated.

\section{Demographic Changes in Workforce's Nature-Talent Shortage in Western Economies}

"Generation Y" employees designate the most diverse generation compared to "generation X" and "baby boomers". For example, nowadays, the vast majority of educated workers (defined as those holding a college degree) are women and/or "people of color", while white males now make up less than $20 \%$ of the global educated workforce (Aguirre et al., 2009). According to the authors, two major factors contributed to this outcome: (1) the growing impact of Chinese and Indian talent within the global marketplace (only 22\% of college graduates come from North America and Western Europe; and (2) an increasing gap among college-educated women and men, with the former outperforming than the latter to college and university graduation.

Kinni et al. (2008) argued that in mature economies the overall aging of their population leads to brain drain of critical skills and institutional knowledge in the workplace. They also noted that in critical sectors, like energy and health care, many people retire, with few skilled employees being available for replacing them. In this regard, the authors highlighted that a "talent shortage" will be apparent, owing to migration tendencies in regions where economic growth creates demand for expert labor (e.g. Middle East, China, India and other booming emerging economies). To that end, they concluded that for those companies operating within the origin points of migration, they will have to cope with such "talent shortages" (Kinni et al., 2008). Despite global recruiting trends, Western Europe still remains the most important source of recruiting according to the survey results of the EIU (2008) survey among 944 executives (587 from developed countries). Hence, it can be said that Western (educated) employees, despite their shrinking tendency, are still considered to be a pool of talented manpower. 


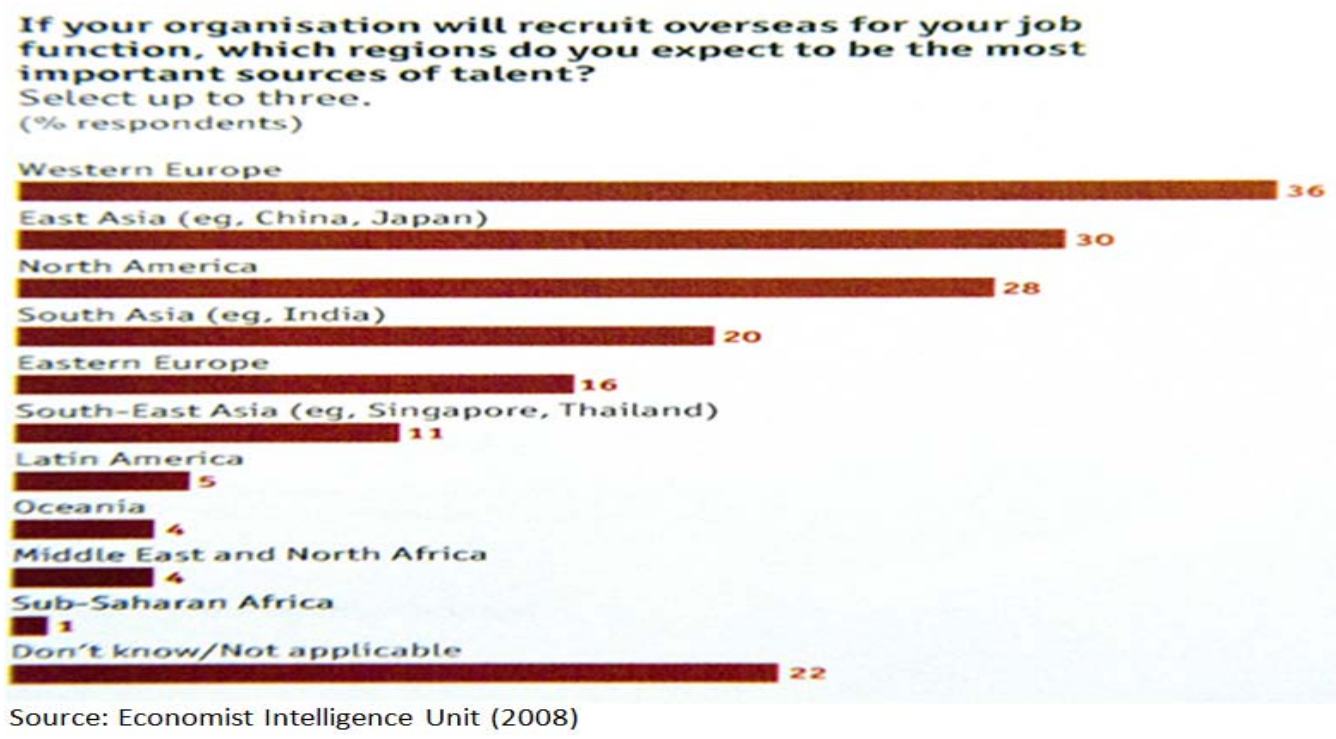

The ageing of population in most Western economies accompanied by low birth rates, both represent additional factors influencing competition within the recruiting process. Kinni et al. (2008) argued that, today, people live longer, however, they have less children. Whilst, globally, life expectancy is estimated to reach 82 in 2050, up from 78 in 2020, concurrently, birthrates are declining at an alarming rate. As reported by Bongaarts (2008), in more than 40 developing countries, fertility rates in 2008 were at/or below replacement levels. More precisely, in US, while total population is mainly increasing, the percentage of those representing the active workforce (people aged 18 to 64) is alarmingly shrinking, owing to baby boomers' "graying" and retirement. Accordingly, in Germany, the active workforce is expected to decline by as much as $29 \%$ by 2050 (United Nations, 2007). Quite similarly, ACAS (2007) reported that: "The working populations are getting older. There are currently 20 million people aged 50 and over in the UK. By 2030 this figure is expected to reach 27 million - an increase of 37\%. Employers will have older workers to recruit and manage and fewer younger employees. They are also more likely to recruit employees with caring responsibilities, with that eventually resulting to an increasing demand of more flexible working policies".

Another important issue of consideration is the increasing "brain-drain" in talented Asian undergraduates, as many decide to get back to their home countries right after their graduation from western universities. In that event, Western countries, that used to keep the exceptional graduates within their workforce pool, are now facing talent shortages in vital, for their national economy, sectors such as the energy industry, engineering, information technology (IT), banking etc. (Kinni et al., 2008). A typical example demonstrating this trend is reported to EIU's (2008) survey, where it is noted that: “In 2007, more than 40.000 Indian IT workers arrived back from US and UK to take up work in Bangalore. Accordingly, more and more students are now returning home after completing their studies in the west, or they choose to study at local universities before applying for jobs in their home markets”.

Apparently, the evaluation of demographic trends is of crucial importance both for 
organizations and societies as part of their efforts to identify the changes occur in workforce's average age, its employment status and income/wealth. Especially for the former, planning the appropriate strategies for following, or even better forecasting demographic trends, would allow them to identify current and future markets for their services and products. Accordingly, customers' emerging needs and marketplace's adjustments would enable organizations to better take business decisions. Appropriately, the demand of a diverse workforce will be highlighted and emerged. In a similar vein, societies need to consider demographic changes when deciding for their educational planning and investments, along with decisions concerning their social security systems.

\section{The "War of Talent"-Business Strategy and Talent Management}

In the context of talent management and organizations' efforts to attract young skilled employees, WLB/FPW practices can offer a significant advantage to those firms following relevant strategies. A vast amount of research identified the aims of such a skilled workforce, and the need of WLB/FPW policies, by outlining three basic objectives for young employees when considering a job offer; firstly, they look for further personal development through training offerings, the acquisition of experience through new tasks, team working and job autonomy. Additionally, in return to their work offer, they seek for appealing rewards. Finally, and most importantly, "generation Y" employees will look for jobs offering WLB incentives (e.g., work flexibility, organizational justice, equity, organizational citizenship etc.) (Korabik et al., 2000a; Gambles et al., 2006; Lewis \& Cooper, 2005; Rapoport et al., 2002). In that event, the work of Heslin (2005) outlined the importance of offering both extrinsic and intrinsic rewards.

Taking into consideration that most of the organizations operating in both developed and developing economies cannot longer guarantee generous remuneration packages, owing to the aftermaths of the recent economic crisis (e.g., lay-offs, downsizings, cost redundancies etc.), WLB/FPW policies appear as an attracting and effective alternative option for employers while recruiting or trying to retain skilled employees. To that end, Bolman and Deal (2008) suggested four practices for captivating the interest of a potential talented workforce or keeping existing one within organizations; these include an alluring compensation scheme, job security, career development options, and various alternative WLB options like job sharing, profit sharing etc. (p.142). Obviously, nowadays, with the advent of the global financial crisis, these practices cannot be assured from many companies. EIU's (2008) survey outlined all of the aforementioned options among some other, as illustrated with the following graph. 


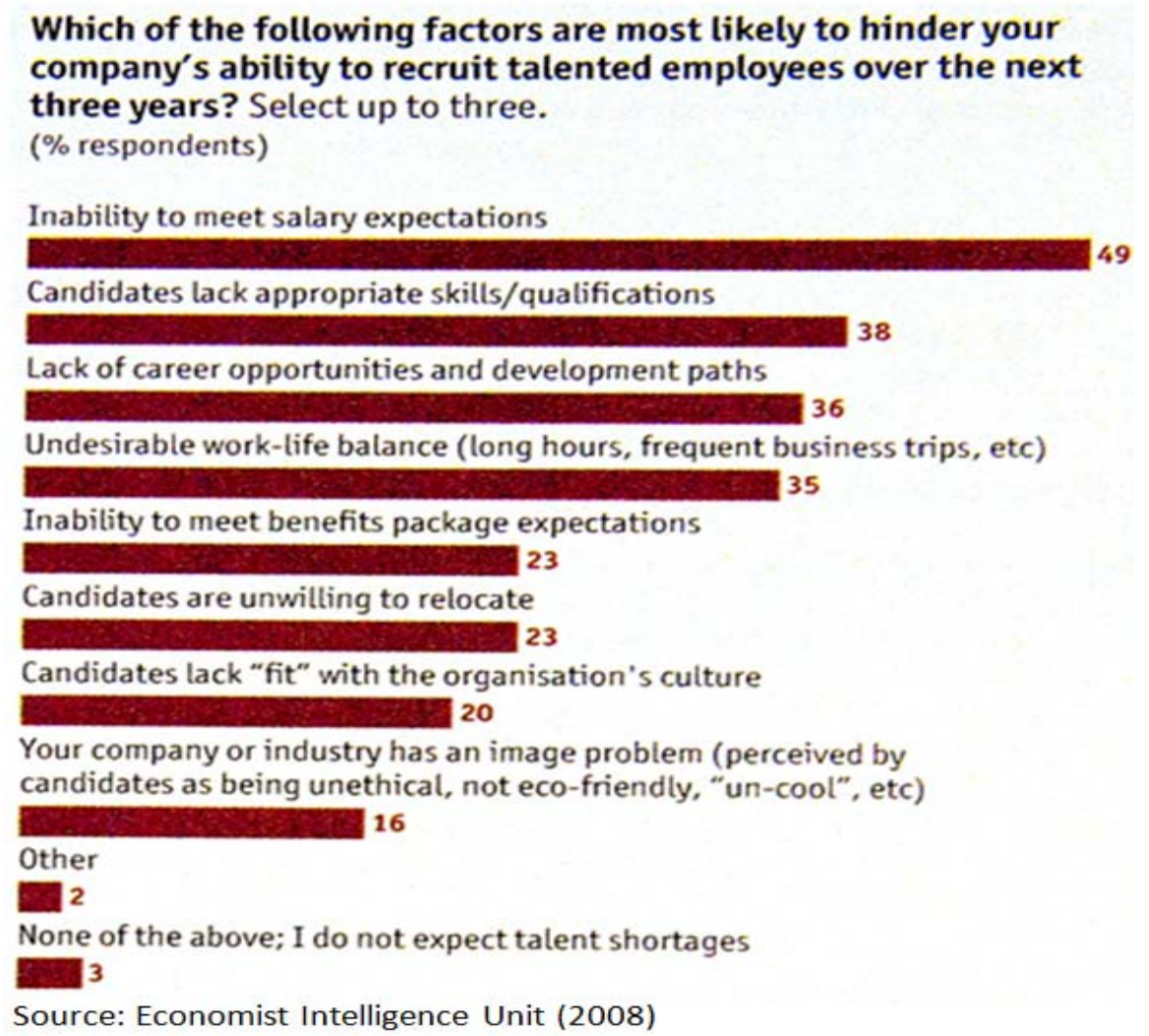

In terms of nations' efforts to retain talented youth within their borders in order to constitute their available and skillful manpower, even high developed countries like US, UK, Germany, and France are not capable of securing the retention of those students (foreigners and nationals) outperforming within their educational institutions. Since personal and career development is a dynamic internal process that initiates throughout people's involvement during their studies and it expands through experiences gained from work, most of them, aiming at enhancing their professional status and development, would eventually move to places offering this option. To that end, as afore stated, certain work populations like engineers and IT professionals prefer to move to regions outside Europe and US.

In this regard, WLB/FPW policies' contribution to "war of talent” (recruitment) and talent management (retention) can be proved of crucial importance. Deery’s (2008) and EIU's (2008) findings, both highlight the most important factors hindering or facilitating recruitment and retention regarding skillful/talented employees of "generation Y". 


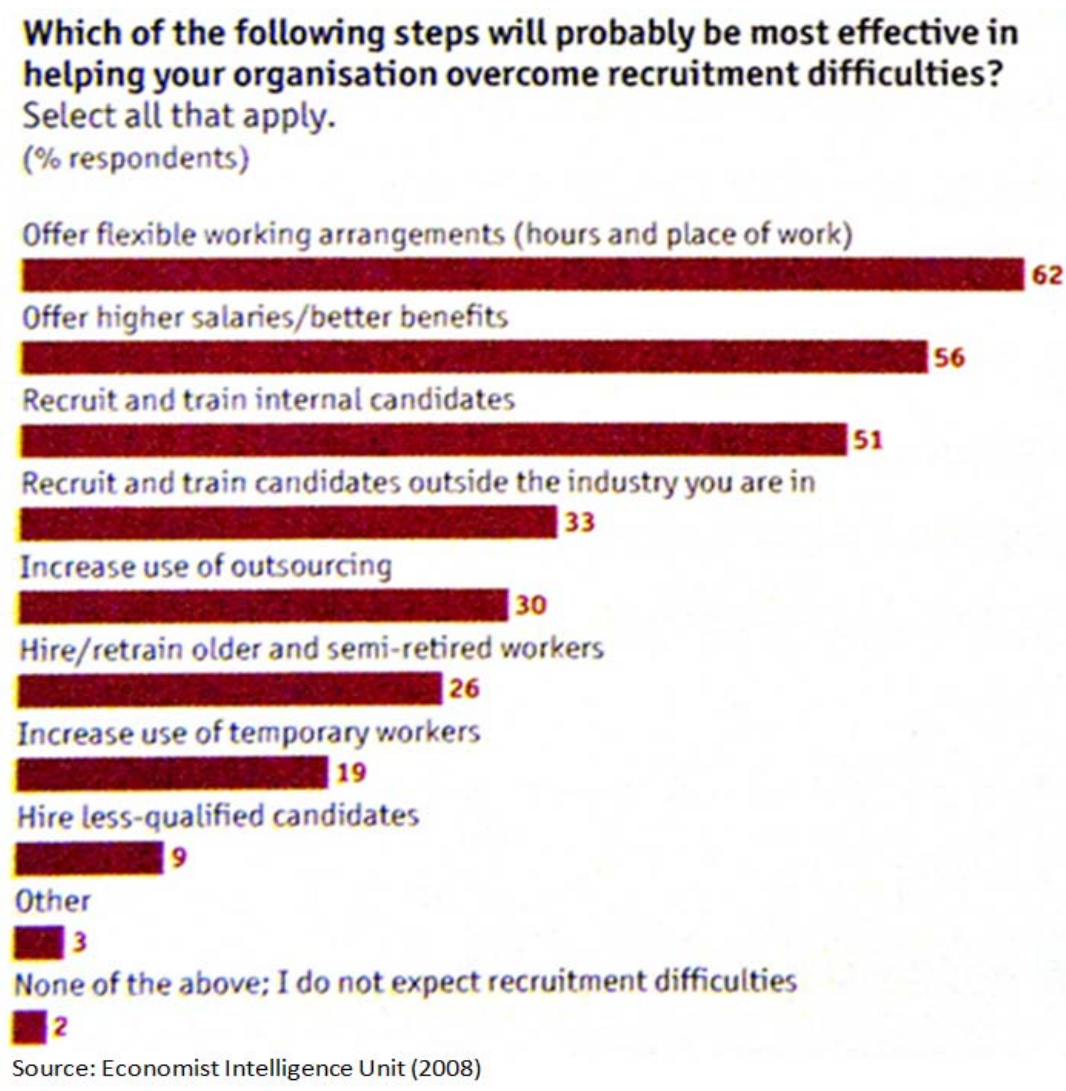

Another piece of evidence, suggesting that employers who support WLB/FPW arrangements and policies are likely to have a competitive advantage within the labor market of the new generation of employees, can be illustrated through the findings of a survey conducted in 44 universities (Personnel Today, 2002). The survey, which was carried out among 6000 students, revealed that: "achieving $W L B$ is the most important consideration for graduates when it comes to choosing an employer". Appropriately, Taylor (2008) argued that "the commitment of employees can make the difference between those companies which compete in the market place and those which cannot. Employers who can best combine the requirements of their business for flexibility with the needs of employees and potential employees will be well placed to succeed". Similar to this view of attracting and retaining employees through employer branding focusing on WLB/FPW approaches, Akin \& Worthen (2008 - in Kinni et al. 2008) noted that: "in order to attract and retain diverse, global workforces and enable them to quickly adapt to constantly changing customer needs and real time demand, organizations must build flexibility into their talent infrastructure. They believe that this flexibility can come in the form of cross-functional or cross business unit career mobility, job sharing, part time work, flexible work schedules, consulting engagements for retirees, and so on. They conclude that the more receptive organizations are to a variety of work arrangements, the better their structure and operations can be shaped to mirror demand, and the more likely they are to be able to attract and retain high-quality employees with the right skills”.

All in all, most of the pressing global challenges firms facing today are strongly related to 
human capital issues. To that end, there is an increasing interest from both the academic literature and the organizations towards a new "global talent management" approach. Based on our discussion, the paper suggests that firms which implement strategic "talent management" policies are those which are going to achieve greater competitiveness and improved performance. However, instead of generalizing that such a strategic approach will result to direct organizational outcomes, we need to recognize the significance of creating a “talent pool” through which multiple outcomes will derive.

\section{Social Trends and Changes within the Traditional Work Environment}

In most Western economies, owing to the decline of fertility rates and the increase in life expectancy, it is expected that aging population will negatively impact on future workforce's state, along with affecting gender's (men/women) responsibilities (Eurostat, 2009). Dual earner couples, in the last decade, were the norms within the workplace, and since financial pressures and work overload still expanding, this tension is expected to continue, resulting in stagnation to birth rates, and eventually to future workforce population's increase in the near future. Additionally, caring (parenting, elder care or third person care) among employees is constantly increasing, leading to Korabik et al. (2008b) assertion of a "sandwich generation", referring to those people who will be forced to provide care to both children and parents due to late-age childbearing and increased life expectancy levels. Furthermore, the proportion of women interrupting their careers or the percentage of talented women choosing to work part-time demonstrates no changes the last years (Gambles et al., 2006; Rapoport et al., 2002). To this extend, ACAS (2007) reported that part time employees make up 25\% of workers in UK, with $80 \%$ of them being women. Apparently, the impact of these tendencies strikes middle class's living standards, which presents the basic source of consumerism in the developed countries, and a vital pool of potential employees for administrative and managerial ranks.

In that event, although organizations are continuously trying to broaden their working structures and operations in order to meet the needs of the modern market, the majority of the western companies still operate upon principles and patterns of the "Weberian" protestant work ethic and framework. Eventually, the tendencies and notions associated with long working hours and workplace's time administration, along with linear and vertical career paths within authoritarian work environments of the 50s and 60s still exist. Moreover, latent notions and stereotypes about ideal workers and non-committed employees that prioritize personal life are also apparent. Even in cases in which organizations reform their structures, and work's context (place, way etc.), the whole effort is addressed solely for meeting customer needs or reducing costs, without equating whether these adjustments or changes meet their employees' needs, which eventually affects their productive behavior.

In order to create a more responsive system to new generation's requirements, along with all other relevant implementations taking place within the workplace, organizations need to clearly understand what kind of workplace and environment those people (generation Y) prefer to work to. In this respect, firms need to address a simple question: "What make their lives easier and what motivates them in this environment?”. To do so, organizations should be 
able to identify demographic changes, along with other influential factors (e.g. globalization, technological advancements, political and economic factors etc.), so making them competent on designing and delivering the most appropriate strategies for ensuring the effective recruitment and retention of the most talented employees. To that end, it is necessary to create a work environment that enables new generations to embody their personalities into their job contexts. Being aware of their needs and aspirations is the first step for changing or adjusting current work patterns into their needs. In this regard, Aguirre et al. (2009) argued that: "think your organizational and career designs. Most organizational designs, career paths, and job descriptions are still based on the rigid hierarchical pyramids of $20^{\text {th }}$-century companies. Career paths are largely vertical, with advancement in pay and responsibility defined incrementally. Talent innovators will rethink the jobs they offer to incorporate greater flexibility, shorter tenures, more efficient training, and more flexible career advancement models".

\section{Conclusion}

Apparently, throughout our discussion, there can be little doubt that "generation Y" workers will constitute tomorrow's workforce. To that end, identifying and understanding their future work behaviours and needs is of crucial importance for organizations. From an employer point of view, WLB/FPW policies, both within the recruitment and retention process and the work environment can enable organizations to better understand how their employees can be more efficient through the implementation of such practices. In that event, it is important to promote a "work-life balance culture" for all employees, and to effectively communicate it to all organizational members. On the other hand, employees would appreciate a greater access to work-life balance initiatives, especially for those categories (e.g., mothers, carers, older people etc.), that will allow them to better meet their objectives. Overall, the importance of designing and offering work-life balance incentives can be clearly illustrated by Pocock (2005) statement that: "Workers who are satisfied with their work-life balance are likely to be happier social citizens, parents, and more productive workers. They may work longer and more productively over their lifetime, making a greater contribution, and their health - along with the health of their dependents and partners - ay be better, reducing public health expenditure and generally increasing social well-being” (p. 202).

\section{References}

Advisory, Conciliation and Arbitration Service (ACAS). (2007). Flexible Working and Work-life Balance (pp. 1-60). Advisory booklet. [Online] Available: http://www.acas.org.uk/media/pdf/4/n/Flexible-working-and-work-life-balance.pdf

Aguirre, D., Hewlett, A. S., \& Post, L. (2009). Global Talent Innovation: Strategies for Breakthrough Performance (pp. 1-26). Booz \& Company Inc. [Online] Available: http://www.strategyand.pwc.com/media/file/Global_Talent_Innovation.pdf

Akin, J., \& Worthen, B. (2008). Managing the Impending Workforce Crisis. In Kinni, T., Steffen, I., \& Worthen, B. (Eds.), Capturing the People Advantage: Thought Leaders on Human Capital (pp. 120-123). Booz and Company Inc. 
Belkin L. (2006). Putting in the Hours and Paying a Price. The New York Times (US). [Online] Available: http://www.nytimes.com/2006/12/03/jobs/03wcol.html?fta=y\&_r=0

Bloom, E. D., \& Canning, D. (2005). Global Demographic Change: dimensions and Economic Significance. Harvard Initiative for Global Health-Program on the Global Demography of Aging, Working Paper No. 1. [Online] Available: http://www.hsph.harvard.edu/pgda/WorkingPapers/2004/working_paper1.pdf

Bolman, G. L., \& Deal, E. T. (2008). Reframing Organizations (4th ed.). John Wiley \& Sons (US), p. 142.

Bongaarts, J. (2008). Fertility Transitions in Developing Countries: Progress or stagnation? Poverty, Gender, and Youth, Working Paper No.7, Population Council. [Online] Available: http://www.popcouncil.org/uploads/pdfs/wp/pgy/007.pdf

Deery, M. (2008). Talent Management, work-life balance and retention strategies. International Journal of Contemporary Hospitality Management, 20(7), 792-806. http://dx.doi.org/10.1108/09596110810897619

Economist Intelligence Unit (EIU). (2008). Talent Wars: The Struggle for Tomorrow's Workforce. A report from the Economic Intelligence Unit, Sponsored by SAP, pp. 1-21. [Online]

Available: http://global.sap.com/australia/partners/pdfs/Talent_Wars_The_Struggle_for_Tomorrow's_ Workforce_.pdf

Economist. (2006). Work-life Balance: Life beyond Pay. Special report (15 ${ }^{\text {th }}$ June 2006). [Online] Available: http://www.economist.com/node/7055931

Eurostat. (2009). The Social Situation in the European Union 2009. European Commission Directorate-General for Employment, Social Affairs and Equal Opportunities. [Online] Available:

http://epp.eurostat.ec.europa.eu/cache/ITY_OFFPUB/KE-AG-10-001/EN/KE-AG-10-001-E N.PDF

Gambles, R., Lewis, S., \& Rapoport R. (2006). The Myth of Work-Life Balance: The Challenge of Our Time for Men, Women and Societies. West Sussex: John Willey \& Sons.

Heslin, P. A. (2005). Conceptualizing and evaluating career success. Journal of Organizational Behaviour, 26(2), 113-136. http://dx.doi.org/10.1002/job.270

Jones, F., Burke, J. R., \& Westman, M. (2006). Work-life Balance: A Psychological Perspective. East Sussex: Psychology Press.

Kerslake, P. (2005). Words from the Ys-Leading the demanding dot-coms. New Zealand Management.

[Online]

Available:

http://www.archivesearch.co.nz/?webid=mgt\&articleid=18347

Kimmel, M. S. (1993). What do Men want? Harvard Business Review, 71(6), 50-63. [Online] Available: http://hbr.org/1993/11/what-do-men-want/ar/5 
Kimmel, M. S. (2000). What do Men want? Harvard Business Review on Work and Life Balance. Boston. HBS Press, pp. 135-163.

Kinni, T., Steffen, I., \& Worthen, B. (2008). Capturing the People Advantage: Thought Leaders on Human Capital. Booz and Company Inc..

Korabik, K., Lero, S. D., \& Whitehead, L. D. (2008a). Handbook of Work-Family Integration: Research, Theory and Best Practices. US: Academic Press.

Korabik, K., McElwain, A., \& Chappell, D. B. (2008b). Integrating gender-related issues into research on work and family. In Korabik, K., Lero, D. S., \& Whitehead, D. L. (Eds.), Handbook of Work-Family Integration: Research, theory, and best practices (pp.215-232). New York: Elsevier.

Levinson, H. (1996). When Executives Burn Out. Harvard Business Review on Work and Life Balance. [Online] Available: http://wweb.uta.edu/management/Dr.Quick/spring2012/When\%20executives\%20burn\%20out .pdf

Lewis S., \& Cooper, L. C. (2005). Work-life Integration. West Sussex: John Willey \& Sons.

Martin, C. (2005). From high maintenance to high productivity: What managers need to know about Generation Y. Industrial and Commercial Training, 37(1), 39-44. DOI: http://dx.doi.org/10.1108/00197850510699965

Morton, L. P. (2002). Targeting Generation Y. Public Relations Quarterly, 47(2), 46-48.

Personnel Today. (2002). Graduates Look for Work-life Balance. [Online] Available: http://www.personneltoday.com/hr/graduates-look-for-work-life-balance/

Pocock, B. (2005). Work-life balance in Australia: Limited progress, dim prospects. Asia Pacific Journal of Human Resources, 43(2), 198-209. http://dx.doi.org/10.1177/1038411105055058

Rapoport, R., Bailyn, L., Fletcher, K. J., \& Pruitt, H. B. (2002). Beyond Work-Family Balance: Advancing Gender Equity and Workplace Performance. San Francisco: Jossey-Bass.

Smith, T. K. (2010). Work-Life Balance Perspectives of Marketing Professionals in Generation Y. Services Marketing Quarterly, 31(4), 434-447. http://dx.doi.org/10.1080/15332969.2010.510724

Taylor, R. (2008). The Future of Work-life Balance. Economic \& Social Research Council, An ESRC Future of Work Programme Seminar Series. [Online] Available: http://societytoday.net/images/future_of_work_life_balance_tcm8-13554.pdf

United Nations. (2007). World Population Prospects: The 2006 Revision. Department of Economic and Social Affairs: Population Division. New York: United Nations. 


\section{Copyright Disclaimer}

2014, Vol. 2, No. 1

Copyright for this article is retained by the author(s), with first publication rights granted to the journal.

This is an open-access article distributed under the terms and conditions of the Creative Commons Attribution license (http://creativecommons.org/licenses/by/3.0/). 